\section{Cellular Physiology} and Biochemistry Published online: December 02, 2015

Accepted: November 04, 2015

This article is licensed under the Creative Commons Attribution-NonCommercial-NoDerivatives 4.0 Intena-

\title{
Power-Frequency Magnetic Field Inhibits Adipogenic Differentiation in Human ADSC
}

\author{
María Antonia Martínez ${ }^{a}$ María Ángeles Trillo ${ }^{a}$ María Antonia Cid ${ }^{a}$ \\ Carlos L. Paíno ${ }^{b}$ Alejandro Úbeda ${ }^{a}$ \\ aServicio de Bioelectromagnetismo-Investigación, IRYCIS, Hospital Universitario Ramón y Cajal, Madrid, \\ Spain, 'bervicio de Neurobiología-Investigación, IRYCIS, Hospital Universitario Ramón y Cajal, Madrid, \\ Spain
}

\section{Key Words}

ELF magnetic field • Stem cells • Adipogenesis • ERK1/2 • PPAR • Sox9

\begin{abstract}
Background/Aims: Semicircular lipoatrophy (SL) is an idiopathic condition characterized by atrophy of subcutaneous fatty tissue. Although several studies have suggested a possible association between $\mathrm{SL}$ and occupational exposure to power frequency magnetic fields (MF), no mechanism has been proposed so far that explains an influence of these fields on adipogenesis. Methods: The study investigates the effects of a $50 \mathrm{~Hz}, 100 \mu \mathrm{T}$ MF on the adipogenesis of stem cells isolated from human adipose tissue (ADSC). Cells were plated in Petri dishes and either exposed intermittently to the field for 42 hours or sham-exposed. Results: Field exposure significantly reduced lipid accumulation within the cells, revealed in Oil Red $\mathrm{O}$ stained samples by spectrophotometry and colorimetry. Early cell passages were particularly sensitive to the effect: $30.40 \pm 5.77 \%$ and $47.96 \pm 12.47 \%$ below controls in the spectrophotometric and colorimetric assays, respectively. Such antiadipogenic effect was accompanied by significant changes in the expression of key effectors/regulators of early adipogenesis: PPAR $\gamma, p$-ERK1/2 and Sox9, indicating that at least the ERK/PPAR $y$ signaling pathway could be involved in the effect. Conclusions: These results constitute an experimental support to the hypothesis that power frequency MF can be one of the factors involved in the etiology of SL.
\end{abstract}

(C) 2015 The Author(s)

Published by S. Karger AG, Basel

\section{Introduction}

Lipodystrophies constitute a heterogeneous group of adipose tissue disorders which are characterized by partial or generalized body fat deficits. Semicircular lipoatrophy (lipoatrophia semicircularis, LS) is an idiopathic lesion characterized by horizontal depression of the subcutaneous fatty tissue, which does not affect the overlying skin or the underlying muscles [1]. In most cases, LS appears at the anterior or antero-lateral portions

María Antonia Martínez

KARGER 125
Investigación-BEM, IRYCIS, Hospital Universitario Ramón y Cajal, Ctra. Colmenar Viejo km 9, 28034-Madrid, (Spain)

Tel. +34 91 7293475, Fax +34 91336 8171, E-Mail m.antonia.martinez@hrc.es 


\section{Cellular Physiology Cell Physiol Biochem 2015;37:2297-2310

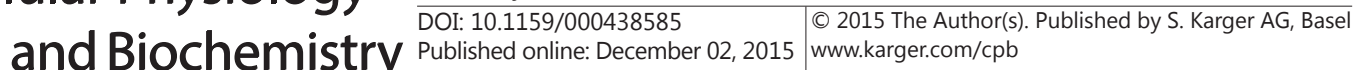 \\ Martinez et al.: Antiadipogenic Effect of Weak $50 \mathrm{~Hz}$ MF}

of the thighs and usually, but not always, affects both limbs quasi-symmetrically [2, 3]. LS is not systematically linked to other symptoms, though individual cases have been described of multiple LS lesions, accompanied or not by distress, cramps and muscle soreness [4]. The first cases of LS were reported by Gschwandtner and Münzberger [5] and the incidence of this condition has increased significantly over the past decades among office workers of a number of countries including Belgium, France, Germany, Italy, Japan, the Netherlands, Spain and the United Kingdom. Since the prevalence of LS among women is six times higher than in men, it has been speculated that such difference could be due to gender dissimilarities in the subcutaneous fat thickness or in other characteristics of the adipose tissue $[1,6]$. Also, stronger aesthetic concerns on the part of women that might result in early detection and declaration of the anatomical lesion, have been proposed as potential contributors to such imbalance [7].

Though the causal factors of LS are not well established yet, several hypotheses have been proposed. Microtraumatisms due to continuous or frequent pressure appear to be a sine qua non factor in the aetiology of LS. In office workers, such microtraumas are produced by repeated friction against the edge of the desks $[4,7,8]$, by pressure exerted by the edge or arms of the chairs [9] or because of the use of tight clothes $[6,10,11]$. However, it becomes evident that friction is a necessary but not sufficient factor.

Thermal energy loss by continuous contact of the legs with a desktop metal frame or cable duct has also been proposed as a possible cofactor [12]. Other hypotheses point to electrostatic discharges or other electrically-related phenomena, including electromagnetic fields generated by computers and electric equipment or wiring, as factors involved in LS aetiology $[1,12,13]$. These hypotheses would receive partial support from preliminary experimental work showing that exposure to sine wave, $50 \mathrm{~Hz}$ magnetic fields (MF) can influence adipogenic processes in adipose tissue-derived stem cells (ADSC) obtained from a human donor [14].

The precursor ADSC are mesenchymal fibroblasts derived from multipotent adipose stem cells that exhibit preadipocytic characteristics [15]. And since ADSC can be isolated, propagated in vitro and induced to differentiate into adipocytes, they represent an ideal model for studying cellular and molecular processes involved in adipogenic differentiation. Such differentiation is controlled by a tightly regulated transcriptional cascade in which the peroxisome proliferator-activated receptor gamma (PPAR $\gamma$ ) and members of the CCAAT/ enhancer-binding protein family (C/EBP) have key roles [16]. In particular, PPAR $\gamma$ is a transcriptional regulator crucial to the process of adipocyte differentiation, both in vitro and in vivo (see $[17,18]$ for reviews) and various types of lipodystrophy have been associated with a decrease or deficiency in the activity of factor PPAR $\gamma[19,20]$. There is a number of different isoforms of PPAR $\gamma$ that are transcribed from the same gene and generate through alternative splicing [21]. The most common of these isoforms are: PPAR $\gamma 1$, which has been reported to express in various tissues, including adipose, skeletal muscle, cardiac or hepatic, and PPAR 2 , which is present almost exclusively in adipose tissue and is specific of mature adipocytes [22].

In turn, the mitogen-activated protein kinases (MAPK) have been proposed as key molecules in the adipogenic differentiation, even if the knowledge on their involvement in such process remains sparse [23, 24]. As for the extracellular-signal-regulated kinase 1 and 2 (ERK1/2), it is a member of the MAPK family and plays a pivotal role in numerous physiological and cellular processes (see [25] for a review). The involvement of the MAPK/ ERK1/2 signaling pathway in adipocyte differentiation has been demonstrated both in vitro, by treating murine cells with MEK1 inhibitors [26] and in vivo, through gene-knockout assays in mice $[23,27]$. The overall evidence from studies in mouse embryonic fibroblasts 3T3L1 reveals that depending on the chronology of its activation, the MAPK/ERK1/2 pathway can up or down regulate adipogenesis. Indeed, whereas ERK1/2 activation promotes differentiation in 3T3-L1 cultures exposed to adipogenic stimulation, delayed activation of ERK1/2 causes inhibition of adipogenesis in that cell line [26]. Actually, recent results on mouse embryo fibroblasts and mesenchymal cells from human omental fat indicate that 


\section{Cellular Physiology Cell Physiol Biochem 2015;37:2297-2310 \\ \begin{tabular}{l|l|l|l|l|l}
\hline DOI: 10.1159/000438585 & $\begin{array}{l}\text { C) } 2015 \text { The Author(s). Published by S. Karger AG, Basel } \\
\text { www.karger.com/cpb }\end{array}$
\end{tabular} \\ Martinez et al.: Antiadipogenic Effect of Weak $50 \mathrm{~Hz}$ MF}

activation of ERK is necessary to initiate the preadipocyte differentiation and, afterwards, this signaling pathway must shut down in order that differentiation can proceed $[28,29]$. However, at present it is not yet clear whether a similar ERK1/2 regulation intervenes in the adipogenic differentiation of human ADSC.

New intracellular signaling pathways involved in adipogenesis continue to be found, and the understanding of the involvement of known regulators is constantly refined. For instance, Wang et al. [30] reported that Sex determining Region Y-box 9 (Sox9) is present in mesenchymal cells and in preadipocytes, and that suppression of Sox9 is necessary before preadipocytes can undertake differentiation into adipocytes. Also, it has been reported that the Preadipocyte factor 1 (Pref-1) prevents down-regulation of Sox9 by activating MAPK/ ERK, which results in inhibition of adipogenesis [31, 32].

On another vein, extremely low frequency magnetic fields are known to influence the in vitro behavior of numerous cell types (see [33] for a review). These changes in normal cell function lead to a variety of effects, depending on different variables (cell type, exposure cycle, specific physical parameters like the signal waveform, etc.) Indeed, electric and magnetic fields at different frequency ranges have been applied successfully in human tissue repair. For instance, electrical stimulation through capacitive coupling, direct current or pulsed magnetic fields, among others, have been used in repair/regeneration of injured tissues [34, 35, 36]. Also, sine wave electromagnetic fields have been shown capable of influencing chondrogenic differentiation $[37,38]$ or promoting osteoblast differentiation and mineralization [39]. Although the basic mechanisms responsible for these effects remain to be identified, it has been reported that exposure to one millitesla $(1 \mathrm{mT})$, sine wave, extremely low frequency (ELF) MF at $15 \mathrm{~Hz}$, used in therapies for prevention or treatment of osteoporosis, stimulates osteocyte differentiation in bone marrow mesenchymal cells, while inhibits adipogenesis and expression of PPAR 2 [40].

On the basis of the above, and taking into account preliminary results by our group, the present study is aimed to assess whether intermittent exposure to MF parameters that have been shown to affect proliferation in human cancer cell lines [41, 42], can influence adipogenic processes in human ADSC. The selected magnetic flux density of $100 \mu \mathrm{T}$ falls within the category of "weak field", as it is well below the Action Levels (AL) established by European Directive 2013/35/EU on occupational exposure to electromagnetic fields [43]. Detection of an antiadipogenic response to weak MF could constitute plausible evidence that power-frequency fields characteristic of some occupational environments could act as physical cofactors in the etiology of LS. Additionally, this study investigates the possibility that the potential antiadipogenic response of ADSC to $50 \mathrm{~Hz}$ MF would occur through changes in the expression of early inductors and/or markers of adipogenesis that could affect the adipogenic differentiation, as well as the synthesis and/or storage of lipids, in these precursor cells.

\section{Materials and Methods}

Isolation and culture of adipose tissue-derived stromal cells

The project and procedures were evaluated and approved by the Clinical Research Ethics Committee of the University Hospital Ramón y Cajal. The stromal-vascular fraction of adipose tissue is the source of both, new adipocytes in vivo [44] and mesenchymal cells in vitro, known as adipose-derived stromal stem cells or ADSC $[45,46]$. ADSC were isolated from the stromal-vascular fraction of disaggregated subcutaneous adipose tissue obtained, as spared tissue during general surgery procedures, from two, non-obese donors (man and woman, aged 65 and 69, respectively) who were free of systemic pathologies and had provided written informed consent. Pieces of about $1 \mathrm{~cm}^{3}$ of fat tissue, freed of surrounding fasciae and visible blood vessels, were collected from each of the two donors. The pieces were minced with scalpels and digested for $40 \mathrm{~min}$ at $37^{\circ} \mathrm{C}$ in collagenase A (Roche Applied Science, San Cugat del Vallés, Barcelona), $1 \mathrm{mg} / \mathrm{ml}$ in alpha-MEM/20\% foetal bovine serum (FBS, Gibco, Paisley, Scotland, UK). To prevent cell clumping due to DNA released from dead cells, DNAse I (Roche Applied Science) was added at $20 \mu \mathrm{g} / \mathrm{ml}$ and the tissue 


\section{Cellular Physiology Cell Physiol Biochem 2015;37:2297-2310 \begin{tabular}{ll|l} 
DOI: 10.1159/000438585 & $\begin{array}{l}\text { O 2015 The Author(s). Published by S. Karger AG, Basel } \\
\text { www.karger.com/cpb }\end{array}$ \\
\hline
\end{tabular} \\ Martinez et al.: Antiadipogenic Effect of Weak $50 \mathrm{~Hz}$ MF}

was dispersed by repeated passage with a P1000 automatic pipette through filtered sterile tips. Larger, undispersed clumps of tissue were cleaned off by filtering the suspension through $100 \mu \mathrm{m}$ mesh cell strainers (BD Biosciences, San Agustin de Guadalix, Madrid, Spain). After centrifugation at $400 \mathrm{~g}$ for $3 \mathrm{~min}$, the floating adipose cells, as well as the rest of the supernatant, were discarded. The pellet was resuspended in $1 \mathrm{ml}$ of MesenPro (Gibco, Invitrogen, Barcelona, Spain) and seeded on a T75 flask with the same medium. The next day, single cells as well as small pieces of capillaries had attached to the plastic surface of the flask. The medium was withdrawn and the flask rinsed twice with Hank's Balanced Salt Solution (HBSS, Sigma-Aldrich, Madrid, Spain), to discard debris and non-attached cells, and the culture was fed again with MesenPro. In approximately one week the culture was confluent. The cells were then detached by mild orbital shaking for $10 \mathrm{~min}$ at $37^{\circ} \mathrm{C}$ in $\mathrm{Ca}^{2+}$ - and $\mathrm{Mg}^{2+}$-free HBSS (Sigma-Aldrich) containing $0.05 \%$ Trypsin/ EDTA (Sigma-Aldrich.) Part of the obtained cells were subcultured at a density of $666 \mathrm{cells} / \mathrm{cm}^{2}$ in new flasks (passage 0), being the media renewed on day 4 after seeding. The remaining cells were pelleted, resuspended in FBS (Gibco) in 10\% DMSO (Sigma-Aldrich), aliquoted in vials and frozen for further use. The cultures at passage 0 became confluent on day $7^{\text {th }}$, at which time they were passaged (passage 1.) The proliferation rate of the cultures remained unchanged for about 6 passages, after which they started to show signs of cellular senescence and were categorized as "late passages" ( $7^{\text {th }}$ to $9^{\text {th }}$ ).

\section{Adipogenic differentiation of ADSC}

Using the appropriate factors, ADSC readily differentiate into adipocytes. The cells were seeded in MesenPro at 2000 cells $/ \mathrm{cm}^{2}$, directly on $60 \mathrm{~mm}$ diameter Petri dishes or on $12 \mathrm{~mm}$ circular coverslips inside 24-well microplates. At day 5 post-plating (time $t=0$ for adipogenesis), the cells reached confluence and the medium was replaced by the adipogenic induction medium: Dulbecco's minimum essential medium (DMEM, Biowhittaker, Lonza, Verviers, Belgium), supplemented with 10\% FBS, 1\% antibiotic-antimycotic, $1 \%$ glutamine (all from Gibco, Invitrogen), and a cocktail of $10 \mu \mathrm{g} / \mathrm{ml}$ insulin, $1 \mu \mathrm{M}$ dexamethasone, $200 \mu \mathrm{M}$ indomethacin (all from Sigma) and 0.25 mM 3-isobutyl-1-metylxanthine (IBMX, Gibco, Invitrogen). During adipogenic differentiation, the medium was renewed every 4 days. Some of the samples were cultured in DMEM (Biowhittaker), supplemented with 10\% FBS, 1\% antibiotic-antimycotic and 1\% glutamine, but without the cocktail; these samples were considered as undifferentiated controls.

\section{Magnetic field exposure}

ADSC cultures were exposed to a $50 \mathrm{~Hz}$, sine wave, linearly polarized magnetic field, at $100 \mu \mathrm{T}$. The exposure set-up was based on that described previously by Trillo et al. [41]. Two identical sets of Helmholtz coil pairs were used, in alternate experimental runs, for MF- or sham-exposure. Each set consisted of two 1000-turn, 20-cm diameter coils made of enamelled copper wire, aligned coaxially $10 \mathrm{~cm}$ apart and oriented to produce vertically polarized MF. The coils were connected to a Newtronic (Model 200MSTPC, Madrid, Spain) wave generator having a $3.53 \mathrm{~mA} \mathrm{DC}$ offset $\left(\mathrm{B}_{\mathrm{DC}}=15 \mu \mathrm{T} \mathrm{rms}\right)$. Once the desired field parameters were set and adjusted using fluxgate magnetometers (Mag-03 Bartington, GMW Assoc, Witney, UK and EFA-3 BN 2245/90.20, Wandel and Goltermann, S.A, Eningen Germany), and during the experiments the MF was constantly monitored using a multimeter (Hewlett Packart, model 974A, Loveland, CO). The two Helmholthz coil sets were placed inside two identical, magnetically shielded chambers (Amuneal Corp., Philadelphia, PA, USA) made of co-netic alloy. The chambers were located inside two identical $\mathrm{CO}_{2}$ incubators (Thermo Scientific, Waltham, MA, USA) with a $5 \% \mathrm{CO}_{2}, 37^{\circ} \mathrm{C}, 90 \%$ humidity atmosphere. The background magnetic field inside the shielded chambers was $\mathrm{B}_{\mathrm{AC}}: 0.06 \pm 0.03 \mu \mathrm{T}(\mathrm{rms}) ; \mathrm{B}_{\mathrm{DC}}: 0.04 \pm 0.03 \mu \mathrm{T}(\mathrm{rms})$. For MF- or shamexposure, cell culture dishes or 24-well microplates were stacked in the central space of the coil sets, where the MF uniformity was maximal $(B=100 \pm 0.1 \mu \mathrm{T})$. MF exposure was administered cyclically, at a $3 \mathrm{~h}$ On $/ 3 \mathrm{~h}$ Off intermittency, which has been shown to elicit a number of in vitro cellular responses [42, 47, 48]. All procedures were conducted blindly for experimental conditions.

\section{Experimental treatments}

The cellular response to $42 \mathrm{~h}$ of intermittent exposure to the MF was studied at two differentiation times (Fig. 1). In the one case, the treatment was initiated at $t=14$ days, i.e., when, after two weeks of adipogenic differentiation, the cells had developed large cytoplasmic lipid droplets (Fig. 1A). In another set of experiments the MF- or sham exposure was initiated at differentiation time $t=0$ (day 5 post-plating) and the analysis was conducted at the end of the $42 \mathrm{~h}$ of MF exposure and/or incubation in adipogenic 


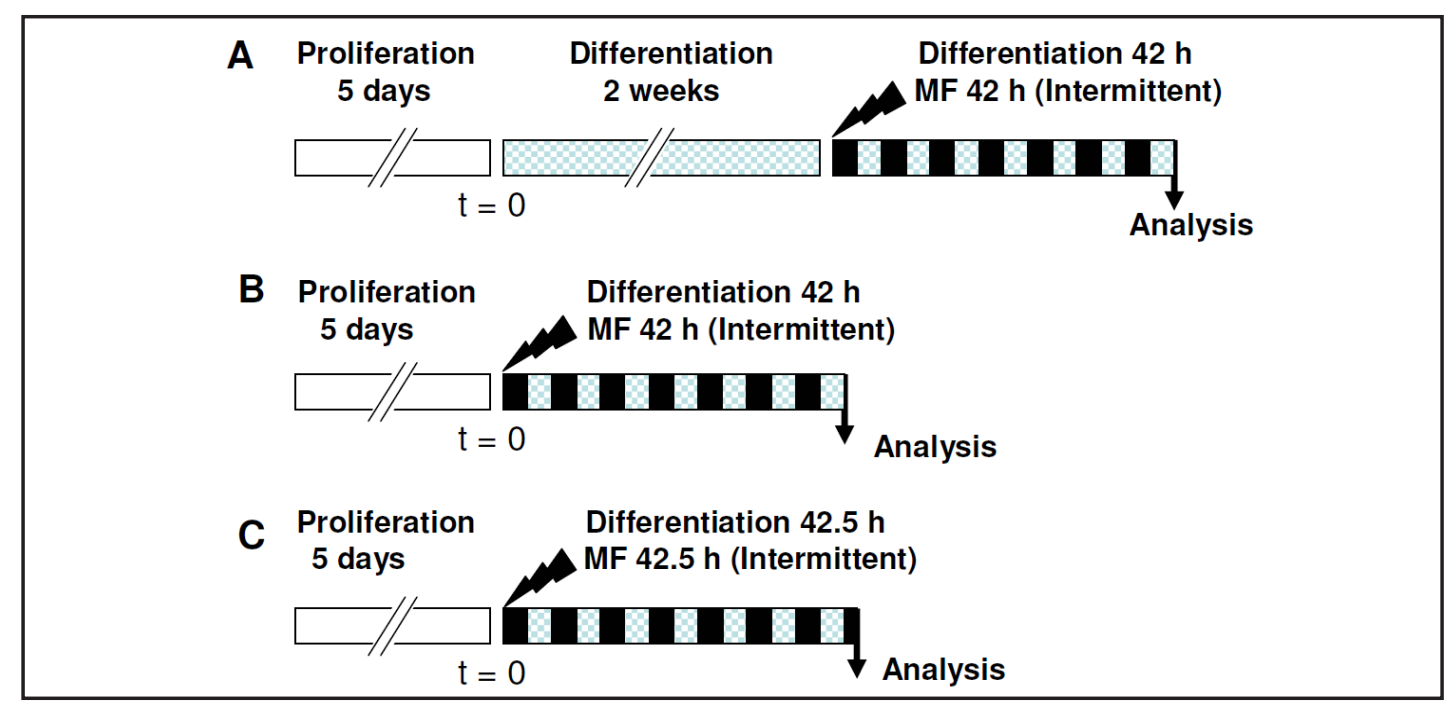

Fig. 1. Experimental protocol: ADSC were seeded and maintained in growth medium for 5 days. At that point, designated as $t=0$, the growth medium was discarded and the cultures received adipocyte differentiation medium. (A) After 2 weeks in differentiation medium, the cultures were submitted for $42 \mathrm{~h}$ to $3 \mathrm{~h} \mathrm{On} / 3$ h Off cycles (black/dotted sectors, respectively, in the time bars) of MF- or sham exposure. (B) The $42 \mathrm{~h}$ of intermittent exposure started at day 5 . As in procedure A, the samples were analyzed at the end of the $42 \mathrm{~h}$ MF- or sham exposure. (C) Same procedure as in B, except that the samples were processed for immunocytochemistry or Western blotting after an additional exposure cycle of $30 \mathrm{~min}$.

medium (Fig. 1B). For immunocytochemical and Western blotting tests, a 30-minute lapse of MF exposure, or sham exposure, was added at the end of the last $3 \mathrm{~h}$ Off interval (Fig. 1C). This extended the total time of intermittent MF- or sham exposure to $42 \mathrm{~h}$ and $30 \mathrm{~min}(42.5 \mathrm{~h})$.

\section{Oil Red $O$ staining}

Assessment of adipogenic differentiation was conducted through quantification of Oil Red O (SigmaAldrich) staining of cytoplasmic lipid droplets. ADSC were plated on coverslips inside 24-well plates and induced to differentiate in the presence or absence of MF. In each of 6 independent replicates or runs of the experiment, 3 MF-exposed coverslips and 3 sham-exposed controls were analyzed. Cells were fixed for $20 \mathrm{~min}$ in $4 \%$ neutral buffered paraformaldehyde, washed in distilled water, and stained for $30 \mathrm{~min}$ with $0.3 \%$ filtered Oil Red 0 solution in $60 \%$ isopropanol. The cells were then washed twice with distilled water. Analysis of lipid content was performed in captured images of Oil Red O-stained samples, using a 20X objective of a Nikon Eclipse TE300 microscope (Melville, USA). Unbiased sampling was achieved by selecting a $5 \mathrm{x} 4$ grid of fields, $1.4 \mathrm{~mm}$ apart, starting from a random position. The total stained area was determined through computer-assisted image-analysis (AnalySIS software: Soft-Imaging Systems GmbH, Münster, Germany).

Additional quantification of lipid content was performed in parallel by spectrophotometry of Oil Red 0 stained samples in the 24-well plates. To extract the dye from the cells, the samples were shaken for 15 min in absolute isopropanol at room temperature. A total of 6 experimental runs were conducted with cultures in passage 5 or earlier, whereas 4 runs were conducted for passage 6 or later. In each experimental run 5 MFexposed and 5 sham-exposed samples were processed. In each run the absorbance of the extracted dye was measured in duplicate at $510 \mathrm{~nm}$ in a CE 2021 spectrophotometer (Cecil-Scharlab, Sentmenat, Barcelona, Spain).

\section{Indirect immunofluorescence}

Cells on coverslips were fixed with $4 \%$ paraformaldehyde, permeabilized with, ethanol/acetic acid $(95 / 5, \mathrm{v} / \mathrm{v})$ for $10 \mathrm{~min}$ at $-20^{\circ} \mathrm{C}$, rinsed 3 times with PBS and blocked with a $10 \%$ normal goat serum in PBS. The samples were incubated overnight at $4^{\circ} \mathrm{C}$ with the corresponding primary antibodies diluted in blocking solution plus $0.05 \%$ Triton X-100. Antibodies to PPAR $\gamma$ from mouse (1:50, Santa Cruz Biotechnology,

\section{KARGER}




\section{Cellular Physiology Cell Physiol Biochem 2015;37:2297-2310 and Biochemistry Published online: December 02, 2015 le $\begin{aligned} & \text { (c) } 2015 \text { The Author(s). Published by S. Karger AG, Basel } \\ & \text { www.karger.com/cpb }\end{aligned}$ \\ Martinez et al.: Antiadipogenic Effect of Weak $50 \mathrm{~Hz}$ MF}

Quimigen, Madrid, Spain) phospho-ERK1/2 from rabbit (1:100, BioSource, LabClinics, Barcelona, Spain) and Sox9 from mouse (1:100, Abnova, Tebu-Bio, Barcelona, Spain) were used. After 3 rinses in PBS, the cells were incubated with anti-mouse-IgG conjugated to AlexaFluor® 546 or anti-rabbit IgG conjugated to AlexaFluor $\AA^{8} 48$ (Molecular Probes, Invitrogen, Prat de Llobregat, Spain). Mounting medium containing antifading solution and $3 \times 10^{-5} \mathrm{M}$ bis-benzimide (Hoechst 33342, Sigma-Aldrich) was used as counterstain for nuclei. The samples were evaluated by photomicroscope (Nikon Eclipse TE300) and computer-assisted image-analysis (AnalySIS software). For each of a total of 4 experimental runs per marker, 3 MF-exposed and 3 sham coverslips were analyzed using the same unbiased sampling strategy as that described above for Oil Red 0 staining.

\section{Western blotting}

Whole cell proteins were prepared by lysing the cells in extraction buffer containing $10 \mathrm{mM}$ Tris HCL (pH 7.6), 100 mM KCL, 1 mM EDTA, 1mM Ditiotreitol, 1 mM phenylmethylsulfonyl fluoride, $10 \mu \mathrm{gr} /$ ml Leupeptin, $5 \mu \mathrm{gr} / \mathrm{ml}$ Pepstatin A, $100 \mathrm{mM} \mathrm{NaF}, 20 \mathrm{mM} \beta$-glycerolphosphate, $20 \mathrm{mM}$ sodium Molibdate, 0.5\% Tritón X-100 and 0.1\% SDS. Protein concentration was determined using the Bradford's colorimetric method Bradford [49]. Samples of $30 \mu$ g of protein were run on 10\% SDS-PAGE and then electrotransferred to nitrocellulose membranes (GE Healthcare, Little Chalfont, Buckinghamshire, UK) with a semi dry system (Bio-Rad, Madrid, Spain). Membranes were blocked with a solution of $0.1 \%$ Tween 20/TBS containing 5\% non-fat milk, for $1 \mathrm{~h}$ at room temperature and then incubated overnight at $4^{\circ} \mathrm{C}$ with appropriate primary antibodies. The membranes were reacted with mouse anti-PPAR $\gamma$ (1:500, Santa Cruz Biotechnology), rabbit anti-phospho-ERK1/2 (1:1,000; BioSource), mouse anti-Sox9 (1:500, Abnova), or mouse anti- $\beta$-actin (1:5,000; Sigma). Horseradish peroxidase-conjugated anti-rabbit IgG $(1: 3,000)$ and anti-mouse $\operatorname{IgG}(1: 2,000)$ (GE Healthcare) were used as secondary antibodies. Immunoreactive bands were detected by ECL Advance Western Blotting Detection Kit (GE Healthcare). The blots were revealed by ECL-chemiluminescence and the obtained bands were evaluated by densitometry (PDI Quantity One 4.5.2 software, BioRad). In each of 18 experimental runs (PPAR $\gamma, \mathrm{n}=6$; $\mathrm{p}$-ERK, $\mathrm{n}=5$; Sox9, $\mathrm{n}=7$ ), 5 MF-exposed samples and 5 sham-exposed controls were studied.

\section{Statistical analysis}

All procedures were conducted in the blind for comparative analysis of the MF-exposed samples vs. sham-exposed samples (differentiating controls), and of the sham-exposed samples vs. undifferentiated controls. Data were normalized and expressed as means \pm standard error (SEM) of at least four independent runs of each experiment, using GraphPad Prism software (Graphpad Software, San Diego, CA, USA). Student's t test was used to compare the data of the mentioned groups. For analysis of protein expression, as measured by immunocytochemistry and Western blotting, multifactorial one-way analysis of variance, ANOVA, followed by the post hoc Bonferroni test was used to assess differences between undifferentiated controls, sham- and MF-exposed groups. The limit of statistical significance was set at $\mathrm{p}<0.05$.

\section{Results}

\section{Magnetic field effect on lipid accumulation during early adipogenesis}

No significant differences existed between the cultures obtained from the two donors in what concerns the respective cell responses to MF exposure (data not shown). Consequently, cells from both donors were used indistinctly in all experiments and the corresponding results were grouped together and analyzed as a whole. When intermittent exposure to MF started after 14 days of incubation in adipogenic medium $(t=14)$ the cell lipid content was not significantly different from that in sham-exposed controls (mean of 4 experimental runs $=2.6 \pm 9.7 \%$ below controls). By contrast, the MF did affect those samples exposed from day 5 post-plating $(t=0)$, in the presence of adipogenic medium (Fig. 2). Indeed, the data show that the field exposure significantly reduced the amount of lipids stored in the cytoplasm of treated cells $(24.19 \pm 7.45 \%$ below their respective sham-exposed samples, also grown in adipogenic medium, $\mathrm{p}<0.01, \mathrm{n}=10$ experimental runs). Such reduction was particularly consistent in early passage cultures $(30.40 \pm 5.77 \%$ below sham-exposed 
Fig. 2. Magnetic field effects on lipid accumulation. Spectrophotometric quantification of Oil Red O-stained vacuolar lipids. Early passages $(n=6$ experimental runs) and passages 6 or later (late, $\mathrm{n}=4$ runs) were incubated in adipogenic medium for $42 \mathrm{~h}$ and simultaneously exposed to MF (Fig. 1B). In each experimental run, 5 control samples and $5 \mathrm{MF}$ exposed samples were processed. Mean \pm SEM, normalized with respect to sham-exposed controls incubated in adipogenic medium. **: $0.001 \leq \mathrm{p}<0.01$; **: $\mathrm{p}<$ 0.001 (Student's t test).

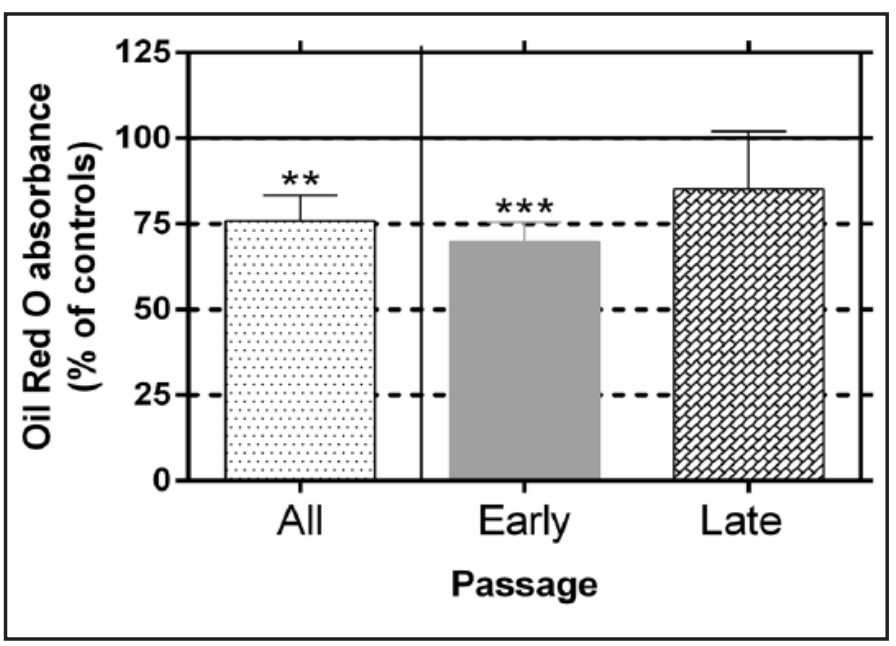

Fig. 3. Microscope analysis for quantification of Oil Red 0 stained areas at early passages. (A) Representative phase contrast micrographs showing reduced area of Oil Red 0-stained lipid droplets in a MF-exposed sample when compared to the sham-exposed controls. (B) Quantification by computer-assisted image analysis of Oil Red O-stained surface in the cultures. In each experimental run 3 coverslips were analyzed per experimental condition. Means \pm SEM from data of 6 experimental runs. ${ }^{* *}: 0.001 \leq p<0.01$ (Student's t test).

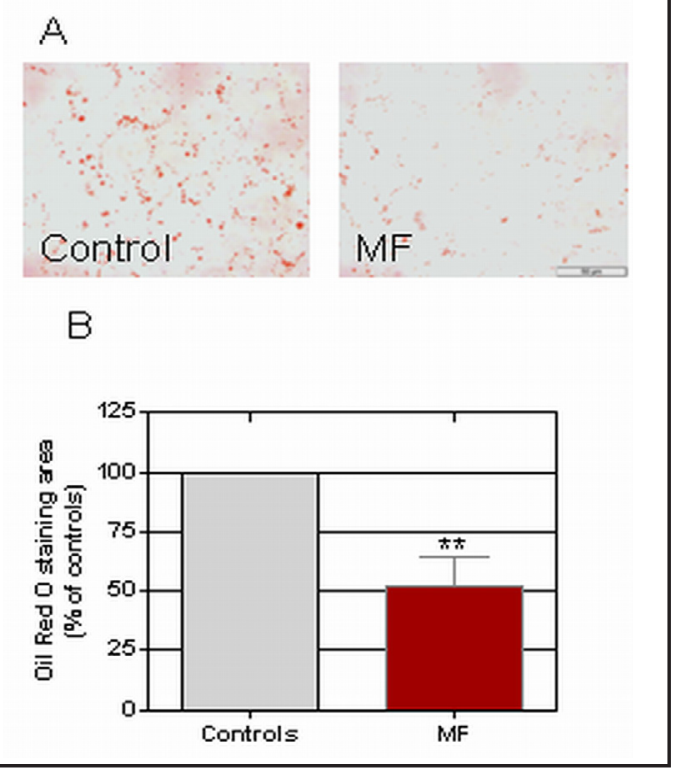

controls, $\mathrm{p}<0.001, \mathrm{n}=6$ experimental runs). This effect revealed by spectrophotometric analysis was confirmed and reinforced by the histochemical study and computer-assisted analysis of micrographic images of the Oil Red 0 stained areas in the cultures. Indeed, the quantification of the percentage of stained surface per microscope field (Fig. 3) revealed a significant reduction in the lipid content of the MF exposed samples $(47.96 \pm 12.47 \%$ below controls, in early passage cultures; $\mathrm{p}<0.01, \mathrm{n}=6$ experimental runs). From these results, it was decided to deepen the study of the response of ADSC submitted from day 5 post-plating to simultaneous treatment with adipogenic medium plus intermittent MF.

Effects of the adipogenic treatment on the expression of PPAR $\gamma, p-E R K 1 / 2$ and Sox 9

The expression or activation of PPAR $\gamma$, ERK1/2, and Sox9, was analyzed in ADSC cultures treated with adipogenic medium during $42.5 \mathrm{~h}$, as in procedure $\mathrm{C}$ of Fig. 1, but in the absence of MF stimulation. The results summarized in Fig. 4A show a significant increase in PPAR $\gamma$ expression ( $191.8 \pm 39.41 \%$; $\mathrm{p}<0.05 ; \mathrm{n}=6$ experimental runs) in differentiated ADSC when compared to their control samples cultured in the absence of adipogenic cocktail. The adipogenic treatment also induced significant decreases in ERK1/2 activation, as assessed by quantification of the expression of p-ERK1/2 (44.44 $\pm 7.4 \%$ of controls; $\mathrm{p}<0.001 ; \mathrm{n}=5$ experimental runs), as well as in Sox 9 expression (19.70 $\pm 6.6 \%$ of controls; $0.01<p<0.05$; 


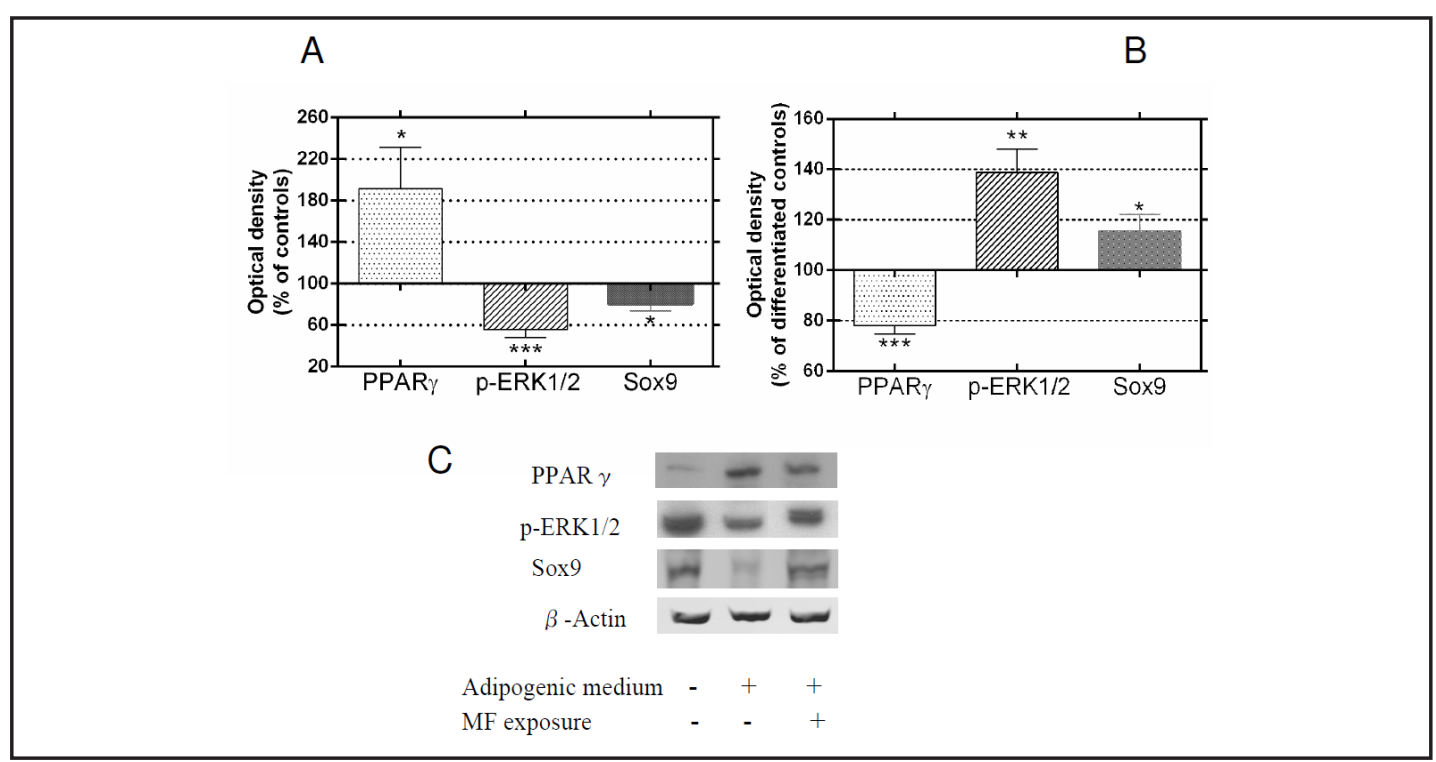

Fig. 4. Western blotting quantification of the expression of PPAR $\gamma, \mathrm{p}-\mathrm{ERK} 1 / 2$ and Sox 9 in ADSC cultured for $42.5 \mathrm{~h}$ in basal or adipogenic medium while exposed or sham-exposed to intermittent MF. (A) Expression of PPAR $\gamma, \mathrm{p}$-ERK1/2 and Sox9 in ADSC cultured for $42.5 \mathrm{~h}$ in adipogenic medium; data normalized over those of controls incubated in basal medium. (B) Densitometric analysis of immunoblots for PPAR $\gamma$, p-ERK1/2 and Sox9 expression in ADSC cultured for $42.5 \mathrm{~h}$ in adipogenic medium while exposed to the MF. Mean \pm SEM values, normalized over sham exposed controls, of band intensity for each protein/ $\beta$-Actin. (C) Representative blots of the proteins in sham exposed control cultures incubated in the presence or absence of adipogenic medium, and of samples treated simultaneously with adipogenic medium and MF. $\beta$-Actin served as loading control. *: $0.01 \leq \mathrm{p}<0.05$; $^{* *}: 0.001 \leq \mathrm{p}<0.01$; $^{* * *}$ : $<<0.001$ (Student's t test).

$\mathrm{n}=7$ experimental runs). Such changes in the expression of these proteins, being consistent with those observed in different cell types undergoing adipocyte differentiation in vitro $[31,50,51]$, indicate that the selected markers may be suitable to the study of the potential influence of the MF on the adipogenesis of ADSC.

\section{Effect of the MF exposure on the expression of PPAR $\gamma, p$-ERK1/2 and Sox 9}

The expression of PPAR $\gamma$, p-ERK1/2 and Sox9 in cultures exposed or not to intermittent MF for $42.5 \mathrm{~h}$ (procedure C, Fig. 1) was analyzed. As illustrated in Fig. 4B, MF exposure significantly reduced PPAR $\gamma$ expression by $21.98 \pm 3.39 \%$ below unexposed, differentiating controls ( $\mathrm{p}<0.001 ; \mathrm{n}=4$ experimental runs). As for phospho-ERK1/2 and Sox 9 expressions, they increased significantly in MF-exposed cultures when compared to that in sham-exposed controls incubated in adipogenic medium (38.74 $\pm 9.35 \%$ over controls, $\mathrm{n}=7$ runs, and 15.56 $\pm 6.51 \%$ over controls, $\mathrm{n}=7$ runs, respectively). Now, it should be noted that, as revealed by the data summarized in Fig. 4A, the expressions of p-ERK1/2 and Sox9 in the presence of adipogenic medium decrease significantly with respect to the background in control samples cultured in the absence of adipogenic supplement. Therefore, the MF-induced increase in the expression of these two markers results in attenuation of the subexpression of both proteins induced by the adipogenic treatment. Figure 5 summarizes the immunocytochemical data on the effects of the 42.5 hour exposure to the MF on PPAR $\gamma, \mathrm{p}$-ERK1/2 and Sox9 expression. The magnetic stimulation significantly decreased the percent of PPAR $\gamma$ positive cells $(27.9$ $\pm 7.16 \%$ below sham-exposed controls incubated in differentiating medium; $p<0.05 ; n=4$ experimental runs) and increased the percents of $p$-ERK1/2 positive cells $(37.25 \pm 2.71 \%$ over that in differentiating controls; $\mathrm{p}<0.001 ; \mathrm{n}=4$ runs) and of Sox9 positive cells (30.04 $\pm 4.48 \%$ over differentiating controls; $\mathrm{p}<0.001 ; \mathrm{n}=4$ experimental runs). These results confirm and support the above described Western blotting data.

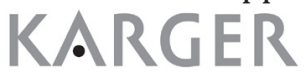



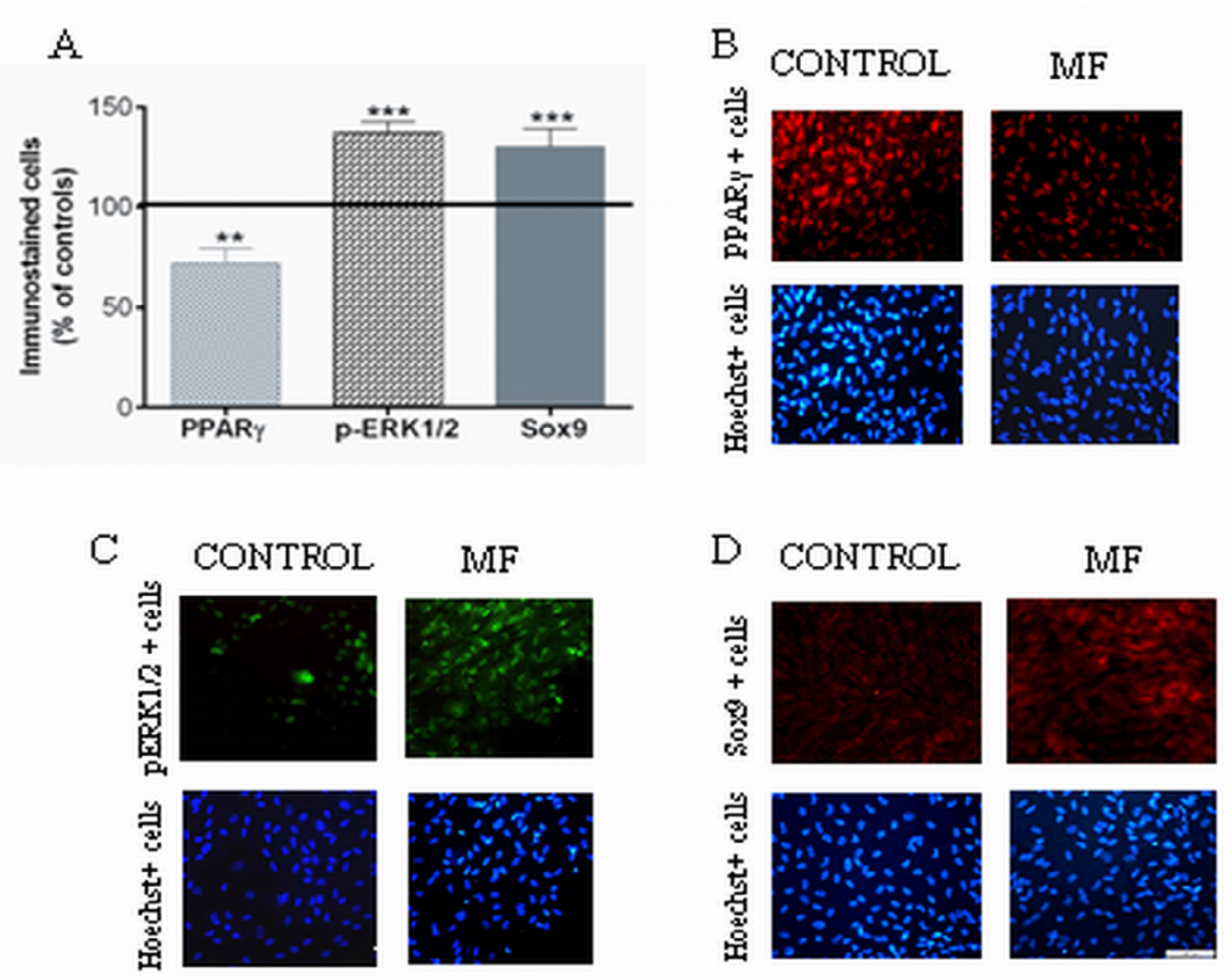

Fig. 5. Immunocytochemical analysis of the MF effects on the expression of PPAR $\gamma$, ERK1/2 and Sox9. (A) Rate of cells expressing PPAR $\gamma, \mathrm{p}$-ERK1/2 and Sox9 in samples incubated in adipogenic medium for $42.5 \mathrm{~h}$ while exposed to the MF. Values are means \pm SEM normalized over those of sham exposed controls. ${ }^{* *}: 0.001$ $\leq \mathrm{p}<0.01$; $^{* * *}$ : $\mathrm{p}<0.001$ (Student's t test). (B, C, D) Representative micrographs of PPAR $\gamma+$ (red) p-ERK1/2+ (green) and Sox 9+ (red) immunostained cells, respectively, after $42.5 \mathrm{~h}$ of MF exposure or sham-exposure (controls). The nuclei of the entire cellular population were Hoechst blue stained, (scale bar $=100 \mu \mathrm{m})$.

\section{Discussion}

This study confirms and reinforces preliminary data showing that exposure to weak, power-frequency magnetic fields, can adversely affect the lipogenic process in stem cells derived from human adipose tissue [14]. The present results reveal that a 42-hour intermittent exposure to a $50 \mathrm{~Hz}$ magnetic field of $100 \mu \mathrm{T}$ significantly reduced lipid content in the cytoplasm of ADSC surgically obtained from adipose tissue of two healthy donors. Such effect would be exerted at an early commitment stage, since significant reduction in fatty acid content was obtained in cultures exposed to the MF during the first $42 \mathrm{~h}$ of chemically-induced adipogenesis, but not in samples exposed after 14 days of adipogenic differentiation.

In addition to the adipogenic phase, other biological parameters such as the culture passage would be also relevant factors in the response to the magnetic field, as only samples in passage 5 or earlier responded to MF exposure with significant changes in fatty acid content. This is coherent with the fact that the immunophenotype of the adipose-derived cells changes progressively with adherence and passage [52] and these changes could determine a differential sensitivity to the field, depending on the biological characteristics of the culture.

On the basis of the observed anti-adipogenic effect, we investigated the field effect on the induction of the transcription factor PPAR $\gamma$, which besides being a central coordinator

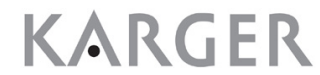




\section{Cellular Physiology Cell Physiol Biochem 2015;37:2297-2310 \\ \begin{tabular}{c|c|c|} 
DOI: 10.1159/000438585 & O 2015 The Author(s). Published by S. Karger AG, Basel \\
www.karger.com/cpb
\end{tabular} \\ Martinez et al.: Antiadipogenic Effect of Weak $50 \mathrm{~Hz}$ MF}

of the adipogenic program, acts as a direct activator of most adipocyte-specific genes, and is responsible for differentiation and lipid storage in adipocytes [53, 54, 55]. In agreement with observations by other authors [56,57], the herein reported results show that PPAR $\gamma$, p-ERK1/2 and Sox 9 are present in ADSC maintained under standard culture conditions, i.e., in the absence of adipogenic medium. However, as predictable, Oil Red 0 staining did not reveal traces of fatty acids in the cytoplasm in these undifferentiated cells (data not shown). Equally predictable was the result that when grown for $42-42.5 \mathrm{~h}$ in proadipogenic culture medium, adipocyte differentiation took place in the form of cytoplasmic accumulation of lipids (Fig. 3), increased expression of the adipogenic transcription factor PPAR $\gamma$ and significant decreases in ERK1/2 activation and in Sox9 expression (Fig. 4A). As for MAPKERK1/2, Prusty et al. [58] provided evidence for a role of this signaling pathway in regulating adipogenesis in 3T3-L1 cells, showing that MEK/ERK can either promote or attenuate adipogenesis, depending on its specific activation time during the differentiation process. Now, in contrast to the negligible basal levels of phosphorylated ERK1/2 found in 3T3-L1 cells by Prusty and co-workers, the present results revealed substantial content of p-ERK1/2 in undifferentiated human ADSC. Concerning its expression during adipogenesis, the activated ERK signal transduction pathway intervenes in the very initial proliferative step of preadipocytic differentiation in 3T3-L1 cells from mouse fibroblast. Subsequently, the ERK pathway has to be shut-off before adipocyte maturation can proceed in 3T3-L1 cells and in preadypose cells from human omental fat $[27,29]$. The possibility that the chronological regulation of the role of ERK in the adipogenesis of these cells is similar to that in human ADSC remains to be investigated. Nevertheless, the herein reported data show that a 42.5hour period of adipogenic induction resulted in significant increases in PPAR $\gamma$ expression and in lipid content, associated with significant downregulation of the ERK pathway. Furthermore, after $42.5 \mathrm{~h}$ of adipogenic induction, significant decrease in Sox9 expression was observed in our ADSC cultures. This is coherent with results reported by Wang and Sul [31] showing that Sox9 downregulation is necessary for adipocyte differentiation, and that preadipocite factor 1, an EGF repeat-containing transmembrane protein, inhibits adipocyte differentiation through upregulation of Sox 9 expression mediated by ERK1/2 activation. Thus, it is thinkable that the herein described inactivation of ERK1/2 is also related to the observed downregulation of Sox9 and adipogenic stimulation.

As for the field effects on adipogenesis, after $42 \mathrm{~h}$ of intermittent exposure, the cells grown in adipogenic medium showed significant reduction in lipid content, associated with significant underexpression of PPAR $\gamma$ and reduced rate of cells expressing PPAR $\gamma$, together with overexpression of p-ERK1/2 and Sox 9 and increased percent of cells expressing p-ERK1/2 and Sox9. Thus, the cell response elicited by the adipogenic medium, involving changes in the three above proteins, was partially inhibited or reverted by the MF exposure. In this line, it has been reported that a $15 \mathrm{~Hz}, 1 \mathrm{mT}$ sine wave magnetic field inhibits adipocyte differentiation, accelerates proliferation and inhibits dexamethasone-modulated adipogenic differentiation in rat bone marrow mesenchymal cells BMSC, being these effects mediated by MEK/ERK $[40,59]$. Our results reinforce the evidence on the relevance of MAPK-ERK in the ELF MF effects on adipogenesis, and show that the MF induces ERK activation during a stage of the adipogenic program of ADSC at which a decline of ERK activity occurs in the control samples. Such a MF effect would result in deregulation of the differentiation process of progenitor ADSC into adipocytes. The possibility that pathways other than those described here are involved in the response to the magnetic field would be worth of being investigated [60-63]. On the other hand, MF are known to activate mitogenic and stress responses in a variety of cell types, and there is evidence that power frequency fields can alter MAPK-ERK1/2 activation in cells from different origins $[42,64,65]$. Furthermore, mitogenic stimulation is known to attenuate PPAR $\gamma$ activity through phosphorylation of its Ser84 site by ERKs [66, 67]. Therefore, MF-induced activation of ERK could lead to decreased activity of PPAR $\gamma$, which would result in adipogenic differentiation delay or blocking. This provides additional support to the hypothesis that MF could act as co-factors in the development of semicircular lipoatrophy, through at least one mechanism involving the ERK/PPAR $\gamma$ signaling pathway. 


\section{Cellular Physiology Cell Physiol Biochem 2015;37:2297-2310 \begin{tabular}{l|l|l|l|l|l}
\hline DOI: 10.1159/000438585 2015 The Author(s). Published by S. Karger AG, Basel \\
www.karger.com/cpb
\end{tabular} \\ Martinez et al.: Antiadipogenic Effect of Weak $50 \mathrm{~Hz}$ MF}

In sum, the present study describes the anti-adipogenic response of human ADSC to two days of intermittent exposure to a $50 \mathrm{~Hz}, 100 \mu \mathrm{T}$ MF. A $100 \mu \mathrm{T}$ magnetic flux density is considered a "weak" field strength according the Action Levels (AL) established by the applicable European Directive [43]. This Directive is meant for protection against immediate harmful effects of occupational exposure to electromagnetic fields, and is based on the recommendations of the International Commission on Non-Ionizing Radiation Protection (ICNIRP) [68]. In fact, the field strength of $100 \mu \mathrm{T}$ corresponds to $10 \%$ and $1.6 \%$ of the High and Low AL, respectively, for whole body exposure to $50 \mathrm{~Hz}$ fields, and to $0.55 \%$ of the AL for limb exposure. Under the chosen experimental conditions, this weak, power frequency field has proved capable of causing disturbances in early stages of the adipocyte differentiation in human ADSC obtained from adipose tissue of healthy donors. Indeed, the MF caused reduction of fatty acid content in the cytoplasm of ADSC, together with alterations in the expression/activation of various factors intervening in the induction/regulation of the adipogenic differentiation program (MAPK-ERK1/2, PPAR $\gamma$ and Sox9). Taken together, these findings support the hypothesis that occupational exposure to weak, power-frequency magnetic fields could act as a co-factor in the etiology of semicircular lipoatrophy.

\section{Acknowledgements}

Study supported by Lipo-Search Project (Cod 810201-904070003) and Fundación MAPFRE (2010/0017). The funders had no role in study design, data collection and analysis, decision to publish, or preparation of the manuscript.

\section{Disclosure Statement}

The authors declare that no competing interest exists.

\section{References}

1 Maes A, Curvers B, Verschaeve L: Lipoatrophia semicircularis: The electromagnetic hypothesis. Electromagnet Biol Med 2003;22:183-193.

2 Mallet RB, Champion RH: Lipoatrophia semicircularis. Br J Dermatol 1981;105:591-593.

3 Bordel Gómez MT: Lipoatrofia semicircular unilateral. Piel 2006;21:414-415.

4 De Groot AC: Is lipoatrophia semicircularis induced by pressure? Br J Dermatol 1994;22:241-243.

5 Gschwandtner WR, Münzberger H: Lipoatrophia semicircularis. Ein beitrag zu bandförmig-circulären atrophien des subcutanen fettgewebes im extremitätenbereich. Der Hautartz 1974;25:222-227.

6 Zafra-Cobo MI, Yuste-Chaves M, Garabito-Solovera E, Santos-Briz A, Morán-Estefanía M, de Unamuno-Pérez P: Pressure-induced lipoatrophia semicircularis. Actas Dermosifiliogr 2008;99:396-398.

7 Gruber PC, Fuller LC: Lipoatrophy semicircularis induced by trauma. Clin Exp Dermatol 2001;26:269-271.

8 Gómez-Espejo C, Bernal-Pérez A, Camacho- Martínez F: A new case of semicircular lipoatrophy associated with repeated external microtraumas and review of the literature. J Eur Acad Dermatol Venereol 2005;19:459-461.

9 Hermans V, Spaepen AJ, Wouters M: Relation between differences in electromyographic adaptations during static contractions and the muscle function. J Electromyogr Kinesiol 1999;9:253-261.

10 Mascaro JM, Ferrando J: Lipoatrophia semicircularis: The perils of wearing jeans? Int J Dermatol 1982;21:138-139.

11 Herane MI, Urbina F, Sudy E: Lipoatrophia semicircularis: A compressive lipoatrophy consecutive to persistent mechanical pressure. J Dermatol 2007;34:390-393.

12 Verschaeve L, Maes A: In vitro investigations related to the hypothesis that lipoatrophia semicircularis finds its origin in electro-stimulation. J Appl Toxicol 2009;29:478-482. 


\section{Cellular Physiology Cell Physiol Biochem 2015;37:2297-2310

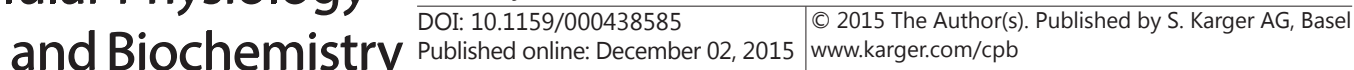 \\ Martinez et al.: Antiadipogenic Effect of Weak $50 \mathrm{~Hz} \mathrm{MF}$}

13 Verschaeve L, Maes A: Support for the hypothesis that electro-stimulation is responsible for lipoatrophia semicircularis. Med Hypotheses 2009;73:802-806.

14 Úbeda Maeso A, Martinez MA, Cid Torres MA, Trillo Ruiz MA, Paíno Belarrinaga, CL: Campos ambientales débiles y lipoatrofia semicircular. Seguridad y Medio Ambiente 2011;123:10-21.

15 Zuk PA, Zhu M, Ashjian P, De Ugarte DA, Huang JI, Mizuno H, Alfonso ZC, Fraser JK, Benhaim P, Hedrick MH: Human adipose tissue is a source of multipotent stem cells. Mol Biol Cell 2002;13:4279-4295.

16 Bishop-Bailey D, Wray J: Peroxisome proliferator-activated receptors: A critical review on endogenous pathways for ligand generation. Prostaglandins Other Lipid Mediat 2003;71:1-22.

17 Siersbaek R, Nielsen R, Mandrup S: PPARgamma in adipocyte differentiation and metabolism--novel insights from genome-wide studies. FEBS Lett 2010;584:3242-3249.

18 Siersbaek R, Nielsen R, Mandrup S: Transcriptional networks and chromatin remodeling controlling adipogenesis. Trends Endocrinol Metab 2012;23:56-64.

19 Guallar JP, Rojas-Garcia R, Garcia-Arumi E, Domingo JC, Gallardo E, Andreu AL, Domingo P, Illa I, Giralt M, Villarroya F: Impaired expression of mitochondrial and adipogenic genes in adipose tissue from a patient with acquired partial lipodystrophy (Barraquer-Simons syndrome): A case report. J Med Case Rep 2008;2:284.

20 Chehab FF: Obesity and lipodystrophy--where do the circles intersect? Endocrinology 2008;149:925-934.

21 Tang QQ, Lane MD: Adipogenesis: From stem cell to adipocyte. Annu Rev Biochem 2012;81:715-736.

22 Farmer SR: Transcriptional control of adipocyte formation. Cell Metab 2006;4:263-273.

23 Bost F, Aouadi M, Caron L, Binetruy B: The role of MAPKS in adipocyte differentiation and obesity. Biochimie 2005;87:51-56.

24 Kortum RL, Costanzo DL, Haferbier J, Schreiner SJ, Razidlo GL, Wu MH, Volle DJ, Mori T, Sakaue H, Chaika NV, Chaika OV, Lewis RE: The molecular scaffold kinase suppressor of ras 1 (ksr1) regulates adipogenesis. Mol Cell Biol 2005;25:7592-7604.

25 Shaul YD, Seger R: The MEK/ERK cascade: From signaling specificity to diverse functions. Biochim Biophys Acta 2007;1773:1213-1226.

26 Tang QQ, Otto TC, Lane MD: Mitotic clonal expansion: A synchronous process required for adipogenesis. Proc Natl Acad Sci USA 2003;100:44-49.

27 Bost F, Aouadi M, Caron L, Even P, Belmonte N, Prot M, Dani C, Hofman P, Pages G, Pouyssegur J, Le Marchand-Brustel Y, Binetruy B: The extracellular signal-regulated kinase isoform ERK1 is specifically required for in vitro and in vivo adipogenesis. Diabetes 2005;54:402-411.

28 Kim KA, Kim JH, Wang Y, Sul HS: Pref-1 (preadipocyte factor 1) activates the MEK/extracellular signalregulated kinase pathway to inhibit adipocyte differentiation. Mol Cell Biol 2007;27:2294-2308.

29 Fuentes P, Acuna MJ, Cifuentes M, Rojas CV: The anti-adipogenic effect of angiotensin ii on human preadipose cells involves ERK1,2 activation and PPARg phosphorylation. J Endocrinol 2010;206:75-83.

30 Wang Y, Hudak C, Sul HS: Role of preadipocyte factor 1 in adipocyte differentiation. Clin Lipidol 2010;5:109-115.

31 Wang Y, Sul HS: Pref-1 regulates mesenchymal cell commitment and differentiation through Sox9. Cell Metab 2009;9:287-302.

32 Lowe CE, O'Rahilly S, Rochford JJ: Adipogenesis at a glance. J Cell Sci 2011;124:2681-2686.

33 Santini MT, Rainaldi G, Indovina PL: Cellular effects of extremely low frequency (ELF) electromagnetic fields. Int J Radiat Biol 2009;85:294-313.

34 Bassett CA, Mitchell SN, Gaston SR: Treatment of ununited tibial diaphiseal fractures with pulsing electromagnetic field. Bone Joint Surg 1981;63A:511-523.

35 Hernandez-Bule ML, Paino CL, Trillo MA, Ubeda A: Electric stimulation at $448 \mathrm{KHz}$ promotes proliferation of human mesenchymal stem cells. Cell Physiol Biochem 2014;34:1741-1755.

36 Assiotis A, Sachinis NP, Chalidis BE: Pulsed electromagnetic fields for the treatment of tibial delayed unions and nonunions. A prospective clinical study and review of the literature. J Orthop Surg Res 2012;7:24.

37 Mayer-Wagner S, Passberger A, Sievers B, Aigner J, Summer B, Schiergens TS, Jansson V, Muller PE: Effects of low frequency electromagnetic fields on the chondrogenic differentiation of human mesenchymal stem cells. Bioelectromagnetics 2011;32:283-290. 


\section{Cellular Physiology Cell Physiol Biochem 2015;37:2297-2310 \begin{tabular}{l|l|l|l} 
DOI: 10.1159/000438585 & $\begin{array}{l}\text { (c) 2015 The Author(s). Published by S. Karger AG, Basel } \\
\text { www.karger.com/cpb }\end{array}$
\end{tabular} \\ Martinez et al.: Antiadipogenic Effect of Weak $50 \mathrm{~Hz}$ MF}

38 Vannoni D, Albanese A, Battisti E, Aceto E, Giglioni S, Corallo C, Carta S, Ferrata P, Fioravanti A, Giordano N: In vitro exposure of human osteoarthritic chondrocytes to ELF fields and new therapeutic application of musically modulated electromagnetic fields: Biological evidence. J Biol Regul Homeost Agents 2012;26:3949.

39 Zhou J, Wang JQ, Ge BF, Ma XN, Ma HP, Xian CJ, Chen KM: Different electromagnetic field waveforms have different effects on proliferation, differentiation and mineralization of osteoblasts in vitro. Bioelectromagnetics 2014;35:30-38.

40 Yang Y, Tao C, Zhao D, Li F, Zhao W, Wu H: EMF acts on rat bone marrow mesenchymal stem cells to promote differentiation to osteoblasts and to inhibit differentiation to adipocytes. Bioelectromagnetics 2010;31:277-285.

41 Trillo MA, Martinez MA, Cid MA, Leal J, Ubeda A: Influence of a $50 \mathrm{~Hz}$ magnetic field and of all-transretinol on the proliferation of human cancer cell lines. Int J Oncol 2012;40:1405-1413.

42 Martinez MA, Ubeda A, Cid MA, Trillo MA: The proliferative response of NB69 human neuroblastoma cells to a $50 \mathrm{~Hz}$ magnetic field is mediated by ERK1/2 signaling. Cell Physiol Biochem 2012;29:675-686.

43 European Parliament and Council. (2013) Directive 2013/35/EU of the European Parliament and of the Council of 26 June 2013 on the minimum health and safety requirements regarding the exposure of workers to the risks arising from physical agents (electromagnetic fields).Official Journal of the European Union 2013;L179/1.

44 Hollenberg $\mathrm{CH}$, Vost A: Regulation of DNA synthesis in fat cells and stromal elements from rat adipose tissue. J Clin Invest 1969;47:2485-2498.

45 Van RL, Bayliss CE, Roncari DA: Cytological and enzymological characterization of adult human adipocyte precursors in culture. J Clin Invest 1976;58:699-704.

46 Zannettino AC, Paton S, Arthur A, Khor F, Itescu S, Gimble JM, Gronthos S: Multipotential human adipose-derived stromal stem cells exhibit a perivascular phenotype in vitro and in vivo. J Cell Physiol 2008;214:413-421.

47 Cid MA, Ubeda A, Hernandez-Bule ML, Martinez MA, Trillo MA: Antagonistic effects of a $50 \mathrm{~Hz}$ magnetic field and melatonin in the proliferation and differentiation of hepatocarcinoma cells. Cell Physiol Biochem 2012;30:1502-1516.

48 Trillo MA, Martinez MA, Cid MA, Ubeda A: Retinoic acid inhibits the cytoproliferative response to weak 50Hz magnetic fields in neuroblastoma cells. Oncol Rep 2013;29:885-894.

49 Bradford MM: A rapid and sensitive method for the quantitation of microgram quantities of proteins utilizing the principle of protein dye-binding. Anal Biochem 1976;72:248-254.

50 Bobrovnikova-Marjon E, Hatzivassiliou G, Grigoriadou C, Romero M, Cavener DR, Thompson CB, Diehl JA: PERK-dependent regulation of lipogenesis during mouse mammary gland development and adipocyte differentiation. Proc Natl Acad Sci USA 2008;105:16314-16319.

51 Donzelli E, Lucchini C, Ballarini E, Scuteri A, Carini F, Tredici G, Miloso M: ERK1 and ERK2 are involved in recruitment and maturation of human mesenchymal stem cells induced to adipogenic differentiation. J Mol Cell Biol 2011;3:123-131.

52 Mitchell JB, McIntosh K, Zvonic S, Garrett S, Floyd ZE, Kloster A, Di Halvorsen Y, Storms RW, Goh B, Kilroy G, Wu X, Gimble JM: Immunophenotype of human adipose-derived cells: Temporal changes in stromalassociated and stem cell-associated markers. Stem Cells 2006;24:376-385.

53 Lefterova MI, Zhang Y, Steger DJ, Schupp M, Schug J, Cristancho A, Feng D, Zhuo D, Stoeckert CJ, Jr., Liu XS, Lazar MA: PPARgamma and C/EBP factors orchestrate adipocyte biology via adjacent binding on a genome-wide scale. Genes Dev 2008;22:2941-2952.

54 Shao X, Wang M, Wei X, Deng S, Fu N, Peng Q Jiang Y, Ye L, Lin Y: Peroxisome proliferator-activated receptor-gamma: Master regulator of adipogenesis and obesity. Curr Stem Cell Res Ther 2015

55 Sul HS: Minireview: Pref-1: Role in adipogenesis and mesenchymal cell fate. Mol Endocrinol 2009;23:17171725.

56 Wajchenberg BL: Subcutaneous and visceral adipose tissue: Their relation to the metabolic syndrome. Endocr Rev 2000;21:697-738.

57 Liu J, Huang J, Lin T, Zhang C, Yin X: Cell-to-cell contact induces human adipose tissue-derived stromal cells to differentiate into urothelium-like cells in vitro. Biochem Biophys Res Commun 2009;390:931-936. 


\section{Cellular Physiology Cell Physiol Biochem 2015;37:2297-2310 \begin{tabular}{ll|l} 
DOI: 10.1159/000438585 & $\begin{array}{l}\text { O 2015 The Author(s). Published by S. Karger AG, Basel } \\
\text { www.karger.com/cpb }\end{array}$
\end{tabular} \\ Martinez et al.: Antiadipogenic Effect of Weak $50 \mathrm{~Hz}$ MF}

58 Prusty D, Park BH, Davis KE, Farmer SR: Activation of MEK/ERK signaling promotes adipogenesis by enhancing peroxisome proliferator-activated receptor gamma (PPARgamma) and C/EBPalpha gene expression during the differentiation of 3T3-L1 preadipocytes. J Biol Chem 2002;277:46226-46232.

59 Song M, Zhao D, Wei S, Liu C, Liu Y, Wang B, Zhao W, Yang K, Yang Y, Wu H: The effect of electromagnetic fields on the proliferation and the osteogenic or adipogenic differentiation of mesenchymal stem cells modulated by dexamethasone. Bioelectromagnetics 2014;35:479-490.

60 Chen Y, Chen L, Yin Q, Gao H, Dong P, Zhang X, Kang J: Reciprocal interferences of TNF-alpha and Wnt1/ beta-catenin signaling axes shift bone marrow-derived stem cells towards osteoblast lineage after ethanol exposure. Cell Physiol Biochem 2013;32:755-765.

61 Chen Y, Gao H, Yin Q, Chen L, Dong P, Zhang X, Kang J: ER stress activating ATF4/CHOP-TNF-alpha signaling pathway contributes to alcohol-induced disruption of osteogenic lineage of multipotential mesenchymal stem cell. Cell Physiol Biochem 2013;32:743-754.

62 Lee SY, Lee JH, Kim JY, Bae YC, Suh KT, Jung JS: BMP2 increases adipogenic differentiation in the presence of dexamethasone, which is inhibited by the treatment of TNF-alpha in human adipose tissue-derived stromal cells. Cell Physiol Biochem 2014;34:1339-1350.

63 Shin KK, Kim YS, Kim JY, Bae YC, Jung JS: miR-137 controls proliferation and differentiation of human adipose tissue stromal cells. Cell Physiol Biochem 2014;33:758-768.

64 Nie K, Henderson A: MAP kinase activation in cells exposed to a $60 \mathrm{~Hz}$ electromagnetic field. J Cell Biochem 2003;90:1197-1206.

65 Goodman R, Lin-Ye A, Geddis MS, Wickramaratne PJ, Hodge SE, Pantazatos SP, Blank M, Ambron RT: Extremely low frequency electromagnetic fields activate the ERK cascade, increase hsp70 protein levels and promote regeneration in planaria. Int J Radiat Biol 2009;85:851-859.

$66 \mathrm{Hu}$ E, Kim JB, Sarraf P, Spiegelman BM: Inhibition of adipogenesis through MAP kinase-mediated phosphorylation of PPARgamma. Science 1996;274:2100-2103.

67 Diradourian C, Girard J, Pegorier JP: Phosphorylation of PPARs: From molecular characterization to physiological relevance. Biochimie 2005;87:33-38.

68 ICNIRP: International commission on non-ionizing radiation protection. ICNIRP statement on the "guidelines for limiting exposure to time-varying electric, magnetic, and electromagnetic fields (up to 300 GHz)". Health Phys 2009;97:257-258. 